\title{
Seabird mortality in the Namibian demersal longline fishery and recommendations for best practice mitigation measures
}

\author{
John R. B. Paterson, Oliver Yates, Hannes Holtzhausen, Tim Reid
}

Kaspar Shimooshili, Sarah Yates, Benedict J. Sullivan and Ross M. Wanless

\begin{abstract}
Seabird bycatch is widely regarded as the greatest threat globally to procellariiform seabirds. Although measures to reduce seabird-fishery interactions have been in existence for many years, uptake in fleets with high risk profiles remains variable. We recorded seabird bycatch and other interactions in the Namibian demersal longline fishery. Interaction rates were estimated for seasonal and spatial strata and scaled up to fishing effort data. Bycatch rates were 0.77 (95\% CI $0.24-1.39$ ) and 0.37 (95\% CI $0.11-$ 0.72 ) birds per 1,00o hooks in winter and summer, respectively. Scaling up to 2010, the most recent year for which complete data are available, suggests 20,567 (95\% CI $6,328-37,935$ ) birds were killed in this fishery that year. We compared bycatch rates to those from experimental fishing sets using mitigation measures (one or two bird-scaring lines and the replacement of standard concrete weights with $5 \mathrm{~kg}$ steel weights). All mitigation measures significantly reduced the bycatch rate. This study confirms the Namibian longline fishery has some of the highest known impacts on seabirds globally, but implementing simple measures could rapidly reduce those impacts. In November 2015 the Ministry of Fisheries and Marine Resources introduced regulations requiring the use of bird-scaring lines, line weighting and night setting in this fishery. A collaborative approach between NGOs, industry and government was important in achieving wide understanding and acceptance of
\end{abstract}

John R. B. PATERSON ${ }^{*}$ and SARAH Yates Albatross Task Force Namibia, Walvis Bay, Namibia

Oliver Yates (Corresponding author) and Benedict J. Sullivan BirdLife International Marine Programme, The Royal Society for the Protection of Birds, The Lodge, Sandy, Bedfordshire, SG19 2DL, UK

E-mail oli.yates@rspb.org.uk

Hannes Holtzhausen Ministry of Fisheries and Marine Resources, Swakopmund, Namibia

Tim ReID $\dagger$ and Ross M. Wanlessł Percy FitzPatrick Institute, Department of Science and Technology/National Research Foundation Centre of Excellence, University of Cape Town, Rondebosch, South Africa

Kaspar SHimooshili Sam Nujoma Campus, University of Namibia, Henties Bay, Namibia

${ }^{*}$ Current address: 6433 Seaforth Street, Halifax, Nova Scotia B3L 1R4, Canada $\dagger$ Also at: Institute for Applied Ecology, University of Canberra, ACT 2617, Australia

¥Also at: Seabird Conservation Programme, BirdLife South Africa, Roggebaai, South Africa

Received 23 August 2016. Revision requested 2 November 2016. Accepted 31 January 2017. First published online 30 May 2017. the proposed mitigation measures in the lead up to the introduction of new fishery regulations.

Keywords Albatross, bycatch, fisheries, mitigation, Namibia, procellariiform, seabirds, white-chinned petrel

\section{Introduction}

Ceabirds are the most threatened group of birds, and more $\checkmark$ than half of all species that spend the majority of their time in open waters (pelagic seabirds) are undergoing population decreases (Croxall et al., 2012). Interactions with fisheries are considered to be one of the principal threats to seabirds, and the impact of longline fishing has been assessed to be at unsustainable levels for populations of some species (Croxall et al., 1990; Weimerskirch et al., 1997), with pelagic seabirds considered to be particularly vulnerable to elevated, anthropogenic adult mortality given their strong K-selected life history traits, such as late onset of reproductive maturity and low fecundity (Furness, 2003). Longline fisheries were first recognized as being a major cause of seabird mortality in the late 1980s and early 1990s (Brothers, 1991; Ashford et al., 1995; Cherel et al., 1996). Those studies demonstrated that seabirds are caught accidentally, dragged under and drown when they scavenge baited hooks during longline setting operations. A complex set of environmental variables that lead to seabird-fishery interactions have been described (Reid \& Sullivan, 2004), but the major factors that contribute to seabird bycatch events in longline fisheries include seabird behaviour (Jiménez et al., 2012) and abundance (Brothers, 1991), slow sink rate of baited hooks (Agnew et al., 2000), and ambient light conditions, including moon phase (Jiménez et al., 2009). Anderson et al. (2011) suggested that the global impact of longline fishing accounts for the mortality of at least 160,000 and potentially $>320,000$ birds annually.

Preventing these negative interactions requires modifications to fishing practices and/or the use of equipment that reduces the likelihood of seabird bycatch, referred to as bycatch mitigation measures (Brothers et al., 1999). Mitigation measures reduce the likelihood of interactions by limiting the access to baited hooks, deterring birds from attacking hooks or reducing the visibility of the hooks during setting operations. The prominent mitigation example of limiting 
access to baited hooks is the use of line weighting. The fastest-sinking hooks are those deployed adjacent to line weights, and the slowest-sinking hooks are those deployed at the mid-point between line weights. Therefore, the interval at which weights are attached to a longline and the mass of the weights are the principal determinants of effective line weighting. Agnew et al. (2000) found that significant reductions in seabird bycatch were possible in the demersal longline fishery targeting toothfish Dissostichus eleginoides around South Georgia, by replacing $4.25 \mathrm{~kg}$ weights at $40 \mathrm{~m}$ intervals with $8.5 \mathrm{~kg}$ weights, effectively doubling the line weighting. Robertson et al. (2008) further investigated fishing gear configurations through a series of optimal sink rate tests and concluded that $8 \mathrm{~kg}$ weights placed at $30 \mathrm{~m}$ intervals was the best gear configuration to reduce seabird bycatch, achieving sink rates of $>0.3 \mathrm{~ms}^{-1}$ to a depth of $10 \mathrm{~m}$. Deterring seabirds from attacking baited hooks before they sink is achieved through the deployment of a birdscaring line during setting operations. Experimental trials have shown that bird-scaring lines can be highly effective, reducing seabird bycatch by $98 \%$ in the North Atlantic (Løkkeborg, 2003). Other studies have shown that multiple bird-scaring lines can be more effective than a single line (Melvin et al., 2001; Reid et al., 2004). Most pelagic seabirds are active during daylight hours and are therefore less susceptible to bycatch at night, so the visibility of hooks during setting can be reduced through night setting operations. However, nocturnal foraging behaviour in some nonalbatross species reduces the effectiveness of night setting as a mitigation measure (Weimerskirch et al., 1999). These three mitigation options can each reduce seabird bycatch rates but it is the combination of line weighting, bird-scaring lines and night setting that is considered to be best practice for mitigation (Bull, 2007; Løkkeborg, 2011; ACAP, 2014). However, gear modifications that increase the sink rate to such a degree that bycatch is eliminated can be a successful alternative to the combination of all three measures (Moreno et al., 2006).

To encourage the adoption of mitigation measures, the Food and Agriculture Organization of the United Nations (FAO) developed an International Plan of Action to reduce the bycatch of seabirds in longline fisheries. This called on member states to develop National Plans of Action that identify the impact of domestic fleets on seabirds and outline the most appropriate mitigation measures (FAO, 1999). Subsequently the FAO published Best Practice Technical Guidelines (FAO, 2008) to assist countries in preparing and implementing National Plans of Action.

In Namibia the first evidence of seabird bycatch was reported by Petersen et al. (2009), which indicated that the Namibian demersal longline fishery for hake could be responsible for the deaths of c. 20,200 birds per year. Although based on a relatively small sample size, this figure places the Namibian demersal longline fishery at the top of the global list of longline fisheries that impact seabirds (Anderson et al., 2011). The species most affected by this fishery, the white-chinned petrel Procellaria aequinoctialis, is categorized as Vulnerable on the IUCN Red List (BirdLife International, 2016a) because of its susceptibility to bycatch in fisheries, predation at nest sites and degradation of breeding habitat (BirdLife International, 2016b). The species is also listed under Annex 1 of the Agreement on the Conservation of Albatross and Petrels (ACAP, 2017), of which Namibia is a signatory state but is yet to ratify.

Here we present new information on the scale of seabird bycatch associated with the Namibian demersal longline fishery from 4 years of observations during commercial fishing operations. We also provide results of experiments testing mitigation measures, and reflect on how a collaborative approach between NGOs, industry and the Namibian government was followed according to the recommendations laid out in the Best Practice Technical Guidelines (FAO, 2008).

\section{Study area}

Namibia is situated in the south-west of the African continent, with a coastline that extends from the Kunene River in the north to the Orange River in the south (Fig. 1). The continental shelf drops to below $1,000 \mathrm{~m}$ within 30 nautical miles of the shore and there are several cold-water upwelling zones along the coast from Lüderitz in the south to Cape Frio in the north. Walvis Bay is centrally positioned on the Namibian coast and forms a natural deep-water port, which is the base for the majority of the fishing companies in Namibia, the remainder operating from Lüderitz.

The Cape hake Merluccius capensis and deep-water hake M. paradoxus are the most important commercial fishery resources in Namibia, although second in volume to the horse mackerel Trachurus capensis (Ministry of Fisheries and Marine Resources, 2013). The fishery is divided into two distinct fleets: demersal trawl and demersal longline. The demersal trawl is the main fishing technique employed to target hake. Demersal longline activities commenced in 1991 with 10 vessels; this had increased to 25 vessels by 2007 (Petersen et al., 2009) but decreased to 10 active vessels (19-55 m in length) in 2013 (Ministry of Fisheries and Marine Resources, 2013). Hake fishing effort is limited to waters $>200 \mathrm{~m}$ deep and extends along the entire Namibian coast. Fishing is concentrated along the continental shelf edge, at a mean depth of $318 \mathrm{~m}$ (range 200-500 m).

\section{Methods}

\section{Fishing gear and operation}

The longline fleet uses a variety of gear configurations to target hake at variable depths (Petersen et al., 2009). Demersal 


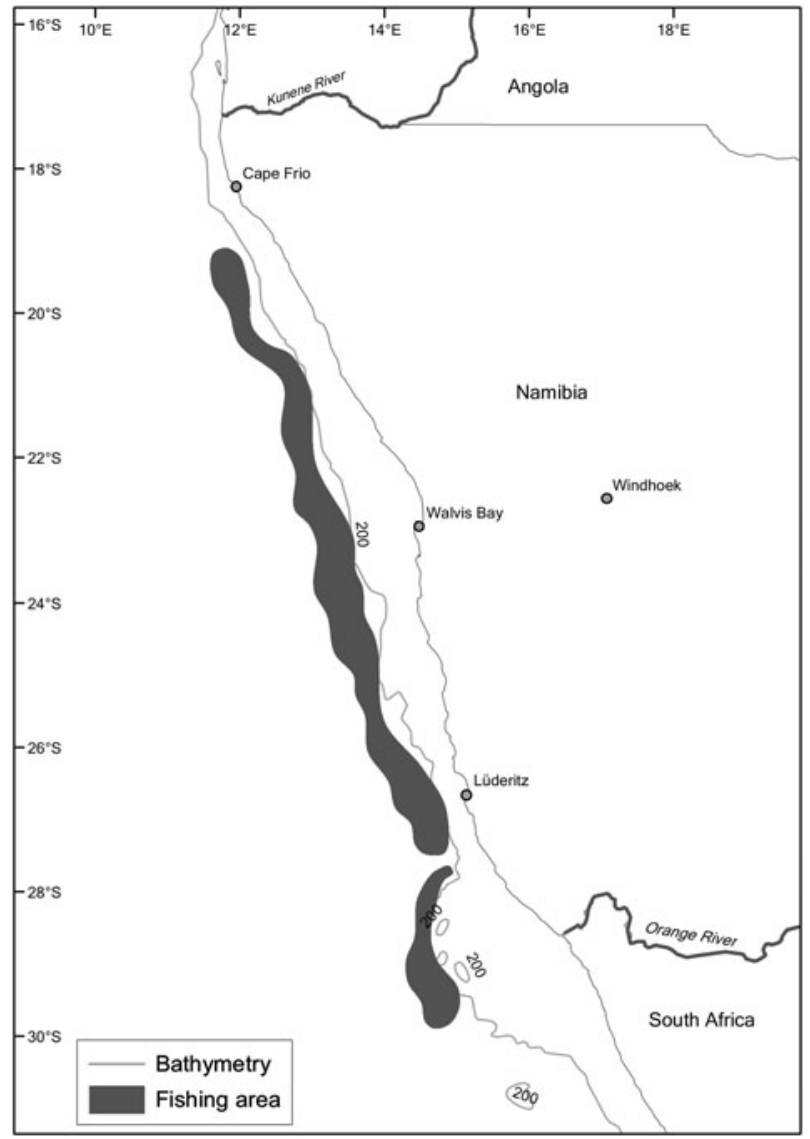

FIG. 1 The area in which demersal longline fishing operations occur off the coast of Namibia.

longline gear is described in detail by Brothers et al. (1999). The configuration used during observations in the current study was representative of the fleet: the double line Spanish system, which included a $15 \mathrm{~mm}$ buoyant main line that supported a braided monofilament nylon hook line. The hook line was divided into $48 \mathrm{~m}$ sections, with alternate dropper lines and weights placed at the intersections. Dropper lines were spaced c. $96 \mathrm{~m}$ apart, with $3.7 \pm \mathrm{SD}$ $1.1 \mathrm{~kg}$ concrete weights placed midway between them. Approximately 60 hooks were attached between dropper lines (c. 1 hook per fathom, or $1.8 \mathrm{~m}$ ). Fishing trips lasted 8 days, on average. One to two lines were set each day; when two lines were set, either the first line was set in shallower water and the second in deeper water parallel to the first, or the lines were set back-to-back. Each line was c. 12.08 nautical miles long (range $7-23 \mathrm{~nm}$ ) and included a mean of 14,292 baited hooks (range 1,111-38,00o hooks) on c. $1 \mathrm{~m}$ monofilament snoods. Typically setting operations started before dawn and continued for up to 2 hours, often continuing into daylight. Lines were set in a north-south or south-north direction. Line hauling began during 10.0011.00 and continued until all gear had been retrieved, with the haul typically completed during oo.00-01.0o the following day.

\section{Data collection}

Observations were conducted on a total of 126 sets during 14 trips on five vessels between May 2009 and July 2012: 11 trips on four vessels to compare bird-scaring lines against a control of no mitigation, and three trips on a single vessel to compare modified line weighting against a control of standard line weighting (Table 1). In total, 1,931,910 hooks were set during this research, including 1,068,368 (55.3\%) with no mitigation, 440,062 (22.8\%) with a single bird-scaring line, 189,709 (9.8\%) with paired bird-scaring lines, and 233,771 (12.1\%) with steel weights. Of these, $1,800,800$ hooks were observed hauled (996,622 with no mitigation, 412,576 with a single bird-scaring line, 176,295 with paired bird-scaring lines, and 215,307 with steel weights), which together represented $93.21 \%$ of all hooks set during monitored trips.

Seabird abundance counts were performed only for daylight setting operations, just prior to the deployment of the first hooks. A single 'snapshot' abundance count for each set recorded the presence and number of each species of bird, both flying and on the water, within a semicircle of radius $250 \mathrm{~m}$ from the central point at the stern of the vessel. Abundance counts required 5-10 minutes to complete. Birds present were recorded to species. All data were collected by one of two experienced observers.

Only data from longline operations in which fishing gear was deployed in the absence of mitigation measures (birdscaring lines or modified line weighting) were used to calculate the baseline seabird mortality estimate. Fishing without mitigation measures was considered to be representative of the standard fishing gear and operation of Namibian demersal longliners. Lines were categorized as night, day or mixed sets according to the following heuristics. Night sets were those that were completed within an hour of nautical twilight, calculated as before 06.00 in summer and before 06.30 in winter; day sets were those that started after 06.00 (both seasons); and sets that started at night and extended into the day (as defined here) were considered to be mixed sets.

Seabird bycatch per unit effort (birds per 1,00o hooks) was recorded to species level based on specimens retrieved during hauling. Line hauling operations were monitored from a position on deck with a clear view of the hauling bay. The observation effort during the haul was estimated by counting weights, which in turn gave the total number of hooks observed. The position of dead birds relative to weights was calculated by counting the hooks between them.

For the purpose of comparing the effectiveness of mitigation measures in this fishery, seabird bycatch per unit effort data were collected using the mortality estimate methodology described above. Mitigation measures included the deployment of bird-scaring lines and modified line weighting during commercial fishing trips. Mitigation and the control treatments are described below. 
TABLE 1 Observer effort for seabird bycatch data collection in the Namibian demersal longline fishery during $2009-2012$.

\begin{tabular}{lccccc}
\hline & $\begin{array}{l}\text { Total } \\
\text { no. of sets }\end{array}$ & $\begin{array}{l}\text { Total no. of } \\
\text { hooks set }\end{array}$ & $\begin{array}{c}\text { \% of total } \\
\text { hooks set }\end{array}$ & $\begin{array}{c}\text { Total no. of hooks } \\
\text { observed hauled }\end{array}$ & $\begin{array}{c}\text { \% of total hooks } \\
\text { observed hauled }\end{array}$ \\
\hline Without mitigation & 72 & $1,068,368$ & 55.30 & 996,622 & 93.28 \\
One bird-scaring line & 24 & 440,062 & 22.78 & 412,576 & 93.75 \\
Two bird-scaring lines & 13 & 189,709 & 9.82 & 176,295 & 92.93 \\
Steel weights & 17 & 233,771 & 12.10 & 215,307 & 92.10 \\
Total & 126 & $1,931,910$ & 100.00 & $1,800,800$ & 93.21 \\
\hline
\end{tabular}

\section{Bird-scaring lines}

Two bird-scaring line configurations (paired and single) were tested against a control treatment of no bird-scaring line. The deployment of paired bird-scaring lines, single bird-scaring lines or the control treatment was allocated on a random basis for each set. Bird-scaring lines were constructed from a $100 \mathrm{~m}$ backbone of $5.0 \mathrm{~mm}$ polypropylene cord. Paired bird-scaring lines of $3 \mathrm{~mm}$ white plastic were attached at $5 \mathrm{~m}$ intervals along the length of the backbone. The first streamer was placed $8 \mathrm{~m}$ from the stern of the vessel and streamers decreased in length from 1.95 to $0.95 \mathrm{~m}$. Tension was provided by a towed device consisting of a buoy tied inside a small traffic cone attached $12.8 \mathrm{~m}$ behind the last streamer at the trailing end of the bird-scaring line.

Bird-scaring lines were attached to extension poles to achieve a height of at least $8 \mathrm{~m}$ above sea level. Extension poles were attached to the aft quarters of the vessel, as far astern as possible. The aerial extension of the bird-scaring line was consistently $90 \mathrm{~m}$.

\section{Line weighting}

Two gear configurations were used to compare the effect of line weighting on seabird mortality: modified $(125 \times 80 \mathrm{~mm}$ $5 \mathrm{~kg}$ solid steel $)$ and standard $(3.7 \pm$ SD $1.1 \mathrm{~kg}$ concrete, $\mathrm{n}=31$ ) line weighting (control). The placement and attachment of steel weights was the same as for standard gear. Steel weights were deployed randomly on either the first or second half of a single long line $(50 \%$ of the gear) or, if two shorter lines were set back-to-back (representing the same effort as one long line), steel weights were placed along one of the two lines.

Sink rate measurements were obtained by placing $\mathrm{G}_{5}$ time-depth recorders (Cefas Technology Ltd, UK) proximal to the slowest sinking hooks (at dropper lines) on each treatment. The recorders were set to record depth (pressure) and time at $1 \mathrm{~s}$ intervals. Before each set the internal recorder time was synchronized with an observer laptop and wrist watch. On deployment, the time the recorders entered the water during the set was recorded to the nearest second. To assess the effect of line weighting on target fish catch, the total weight of hake caught on each treatment was recorded from the captain's logbook to give a catch per unit effort (kg per 1,00o hooks).

\section{Data analysis}

Analysis was performed using $R$ v. 3.3.1 (R Development Core Team, 2013). Seabird bycatch data from all years were grouped, under the assumption that there were no changes in fishing gear, operation, distribution or seabird assemblage between years. Data were then stratified to obtain the spatio-temporal bycatch per unit effort for summer (October-March) and winter (April-September), to coincide with differences in seabird abundance in the Benguela Current. Fishing closures in October meant no data were available for that month in any year. Data were also stratified into three geographical zones: North $\left(17-20.99^{\circ} \mathrm{S}\right)$, Central $\left(21-25.99^{\circ} \mathrm{S}\right)$ and South $\left(26-30^{\circ} \mathrm{S}\right)$. However, there were insufficient data in the North and South zones to treat them separately.

Seabird mortality was compared between seasons. Seabird mortality on longlines is an inherently Poisson process, as observations are integer counts. As the data were overdispersed, we compared seasonal data using a negative binomial general linear model from the MASS v. 7.3-45 library in $R$ (Venables \& Ripley, 2002). An offset for the log of the number of hooks set was added to account for variation in effort.

Fleet effort data for 2010 were provided by the Ministry of Fisheries and Marine Resources. These data were stratified, as for observed effort, to estimate total fishing effort per season and per geographical zone. Total annual seabird mortality estimates were then calculated by applying the observed bycatch per unit effort to the relevant effort data for each stratum, following the approach of Maree et al. (2014). By combining the resulting figures for each season and fishing zone an annual bycatch estimate was derived for the fleet.

A hierarchical, non-parametric bootstrap procedure was performed on seasonal data using resampling (Shotwell, 2013) to create confidence intervals around the estimate and reduce the effects of zero inflated data. Bootstrap resampling was performed with 2,00o repetitions for each season, using year, season, trip and line as sample units, and bycatch per unit effort as the response variable. For a hierarchical bootstrap, rather than resampling from all observations as if they are independent, samples are taken initially from the first level of the hierarchy (in this case year), then from the second level (season) within the year, and then down each level until the observations are sampled 
(Shotwell, 2013). Treating the observations as independent would result in unrealistically narrow confidence intervals.

Seabird bycatch per unit effort from each mitigation scenario were compared using a negative binomial general linear mixed effects model, as observed mortality was based on count data and was overdispersed for a Poisson distribution. A negative binomial distribution provided a good fit to the data. To test each scenario, three models were used, each with total mortality (number of birds) as a response variable, with $\log$ offset of the number of hooks observed to control for observer effort. Trip, year and season were added as random terms. Each model then included one fixed effect, number of bird-scaring lines, whether steel weights were used, and time of day of each set. Data were subsampled for each model, so that for testing the bird-scaring lines, all sets used concrete weights, and for testing steel weights, all sets were without bird-scaring lines. Modelling was performed using the $R$ package lme4 v. 1.1-7 (Bates et al., 2015). In addition to testing total bird mortality, we tested the effects of time of day on albatrosses. Because of the relatively low number of albatrosses caught (29 of 573 birds caught when no mitigation measures were used), the data were zero-inflated and fitted a negative-binomial model poorly. Hence a zero-inflated Poisson model was fitted to the albatross data using JAGS v. 4.2.o (Plummer, 2015). There were insufficient positive data (excess zeros) for adding Trip and Year random terms to the model, hence the evidence of differences may be overestimated. Model goodness of fit was performed using posterior predictive checking (Gelman et al., 2014).

Time-depth recorder data were extracted by selecting data logged from water entry time (zero seconds) onwards, for each deployment. The mean time to reach a depth of 2, 4 and $6 \mathrm{~m}$ was then calculated from all recorder data combined under each treatment: steel $5 \mathrm{~kg}$ weights and standard concrete weights (Robertson et al., 2008). This mean was then used to calculate the sink rate $\left(\mathrm{ms}^{-1}\right)$ per treatment, and sink rates were compared using a Student's $t$-test.

The catch per unit effort ( $\mathrm{kg}$ per 1,00o hooks) of hake caught on sets using modified and standard line weighting was calculated during line hauling observations. No differentiation was made between hake species as this would have required a more detailed examination of individual fish. The catch per unit effort for target species between line weighting treatments was compared using a Student's $t$-test.

\section{Results}

\section{Seabird abundance}

Eight seabird species were observed during 26 seabird abundance counts made during setting operations. The most frequently occurring species was the white-chinned petrel, which was present in all surveys and was the most numerous by mean (36.27 \pm SD 27.89) and maximum (105) number present during counts (Table 2). Other frequently observed species included the Atlantic yellow-nosed albatross Thalassarche chlororhynchos ( $80.77 \%$ of counts), the brown skua Catharacta antarctica (38.46\%) and the blackbrowed albatross Thalassarche melanophris (30.77\%).

\section{Seabird mortality}

A total of 633 seabirds (mean $=5 \pm$ SD 10.76, range $0-72$ ) were retrieved during hauling observations. Of the $126 \mathrm{ob}-$ served sets, 6o $(47.6 \%)$ had incidents of seabird bycatch. Of the 633 birds retrieved, 573 (90.52\%) were caught on 45 of the 72 sets $(62.5 \%)$ deployed in the absence of mitigation $($ mean $=7.96 \pm \mathrm{SD} 13.36$, range $0-72): 486(84.82 \%)$ whitechinned petrels, 43 (7.50\%) Atlantic yellow-nosed albatrosses, 22 (3.84\%) black-browed albatrosses, nine (1.57\%) brown skuas, eight (1.40\%) sooty shearwaters Ardenna grisea and five (0.87\%) Cape gannets Morus capensis (Table 3 ).

Hooks set in the absence of mitigation measures from all trips were included in the baseline seabird bycatch estimate. During 2009-2012 72 sets $(1,068,368$ hooks, $57 \%$ of all sets monitored) were deployed in the absence of mitigation.

The hierarchical non-parametric bootstrap performed on seasonal data for sets in which no mitigation measures were used included a total of 51 sets in winter and 21 in summer. The resulting bycatch rates were 0.77 (95\% CI $0.24-$ 1.39) and 0.37 (95\% CI $0.11-0.72$ ) birds per 1,00o hooks for winter and summer, respectively. Bycatch rates were not significantly different between seasons $(z=1.394, \mathrm{P}=0.163)$. Nevertheless, because the difference in rates between seasons was substantial, we considered them to be sufficiently important to stratify the estimates of total mortality.

According to data from the Ministry of Fisheries and Marine Resources a total of 1,852 sets and 34,766,227 hooks were deployed throughout 2010 by the demersal longline fleet: 819 sets and 15,508,119 hooks in summer and 1,033 sets and 19,258,108 hooks in winter. Based on observed bycatch and available fishery effort data we estimate that $20,567(6,328-37,935)$ birds were killed in 2010 in the Namibian demersal longline fishery: $5,738(1,706-11,166)$ in summer and $14,829(4,622-26,769)$ in winter.

\section{Mitigation measures}

The bycatch rate of seabirds when either one or two birdscaring lines were used was 0.04 and 0.06 birds per 1,000 hooks, respectively. These bycatch rates are significantly lower than for control lines (0.57 birds per 1,000 hooks) on which no bird-scaring lines were used (general linear mixed-effects model: $t=-5.03, \mathrm{P}<0.001$ and $t=-3.55$, $\mathrm{P}<0.001$, respectively). No albatrosses were caught during 
TABLE 2 Maximum and mean numbers of birds, and frequency of observation of species recorded during seabird abundance counts $(\mathrm{n}=$ 26) aboard vessels in the Namibian demersal longline fishery.

\begin{tabular}{lccc}
\hline Species & Maximum & Mean \pm SD & Frequency of observation (\%) \\
\hline White-chinned petrel Procellaria aequinoctialis & 105 & $36.27 \pm 27.89$ & 100 \\
Atlantic yellow-nosed albatross Thalassarche chlororhynchos & 100 & $30.18 \pm 28.03$ & 80.77 \\
Brown skua Catharacta antarctica & 81 & $28.09 \pm 29.76$ & 38.46 \\
Black-browed albatross Thalassarche melanophris & 98 & $25.50 \pm 32.90$ & 30.77 \\
Shy albatross Thalassarche cauta & 90 & $30.33 \pm 32.06$ & 26.92 \\
Wilson's storm petrel Oceanites oceanicus & 130 & $23.50 \pm 47.63$ & 23.07 \\
Cape gannet Morus capensis & 22 & $09.67 \pm 06.97$ & 23.07 \\
Sabine's gull Xema sabini & 60 & $36.50 \pm 36.50$ & 15.38 \\
\hline
\end{tabular}

TABLE 3 Total number of birds observed hooked and drowned and catch rate (birds per 1,0oo hooks) in the Namibian demersal longline fishery, by species and mitigation measure used.

\begin{tabular}{|c|c|c|c|c|c|c|c|}
\hline Treatment & $\begin{array}{l}P . \\
\text { aequinoctialis }\end{array}$ & $\begin{array}{l}\text { C. } \\
\text { antarctica }\end{array}$ & $\begin{array}{l}T . \\
\text { chlororhynchos }\end{array}$ & $\begin{array}{l}\text { T. } \\
\text { melanophris }\end{array}$ & $\begin{array}{l}\text { Ardenna } \\
\text { grisea }\end{array}$ & $\begin{array}{l}\text { Morus } \\
\text { capensis }\end{array}$ & Total \\
\hline $\begin{array}{l}\text { Control (no } \\
\text { mitigation) }\end{array}$ & $486(0.49)$ & $9(0.01)$ & $43(0.04)$ & $22(0.02)$ & $8(0.01)$ & $5(0.01)$ & $573(0.57)$ \\
\hline One bird-scaring line & $16(0.04)$ & $0(0.00)$ & $0(0.00)$ & $0(0.00)$ & $0(0.00)$ & $0(0.00)$ & $16(0.04)$ \\
\hline $\begin{array}{l}\text { Two bird-scaring } \\
\text { lines }\end{array}$ & $11(0.06)$ & $0(0.00)$ & $0(0.00)$ & $0(0.00)$ & $0(0.00)$ & $0(0.00)$ & $11(0.06)$ \\
\hline Steel weights & $29(0.13)$ & $0(0.00)$ & $1(0.00)$ & $2(0.01)$ & $0(0.00)$ & $0(0.00)$ & $33(0.15)$ \\
\hline Total & $542(0.72)$ & $9(0.01)$ & $44(0.05)$ & $24(0.03)$ & $9(0.01)$ & $5(0.01)$ & $633(0.83)$ \\
\hline
\end{tabular}

sets with bird-scaring lines deployed. When steel weights were used the bycatch rate was 0.15 birds per 1,00o hooks, which was significantly lower than bycatch rates when no mitigation measures were used (general linear mixed-effects model: $t=-2.294, \mathrm{P}<0.01 ;$ Fig. 2 ). No difference was found between total seabird bycatch rates for day, night or mixed sets $(t=0.018, \mathrm{P}=0.991)$. Plots of posterior predictive tests of the zero-inflated Poisson model of albatross mortality indicated a reasonable fit with no systematic biases. From the model, in winter, during the day albatrosses were estimated to be killed at a rate of 0.13 birds per 1,00o hooks ( $95 \%$ credible interval (c.i.) $0.05-0.26$ birds per 1,000 hooks). In the winter, during the night the estimated albatross bycatch rate was 0.02 birds per 1,000 hooks (c.i. 0.01-0.06 birds per 1,00o hooks) and did not overlap with the day rate (at $99 \%$ overlap). There were insufficient data for a reliable estimate of catch rate for the mixed period (mean 0.19 birds per 1,000 hooks; c.i. 0.01-1.04 birds per 1,00o hooks). We estimated that albatrosses were caught on $13 \%$ (c.i. $6-24 \%$ ) of sets.

Comparative trials of the sink rate between standard concrete weights and $5 \mathrm{~kg}$ steel weights involved a total of 222,771 hooks (on 17 lines) with steel weights and 142,489 hooks (on 13 lines) with concrete weights. Time-depth recorder data indicated that steel weights reached depths of 2, 4 and $6 \mathrm{~m}$ at a faster sink rate than lines set with concrete weights, by $0.04,0.05$ and $0.06 \mathrm{~ms}^{-1}$, respectively (Student's $t$-test: $\mathrm{P}<0.05)$. Thus, at a setting speed of 8 knots, baited hooks set on lines with steel weights reach a depth of $6 \mathrm{~m}$ at a distance of $132 \mathrm{~m}$ astern, compared to $189 \mathrm{~m}$ astern for hooks set on lines with concrete weights (Table 4).

\section{Seabird bycatch in relation to line weighting}

The distance at which birds were captured from a line weight was recorded for 76 birds. More than $90 \%$ of birds caught were recovered $>25 \mathrm{~m}$ from a line weight, and no birds were caught within $15 \mathrm{~m}$ of a line weight (Fig. 3).

\section{Target species catch}

From 16 sets monitored for fish catch, 49,547 kg of the target species was caught on lines set with steel weights, at a catch rate of $235 \mathrm{~kg}$ per 1,00o hooks, whereas $38,856 \mathrm{~kg}$ was caught on lines set with concrete weights, at a catch rate of $273 \mathrm{~kg}$ per 1,0oo hooks. We found no significant effect of using increased mass of steel weights on hake catch per unit effort compared to the traditional concrete weights (Student's $t$-test: $\mathrm{P}>0.05)$.

\section{Discussion}

\section{Summary of findings}

This study provides an update to the seabird mortality estimate for the Namibian demersal hake longline fleet of 20,200 birds reported by Petersen et al. (2009). Despite 

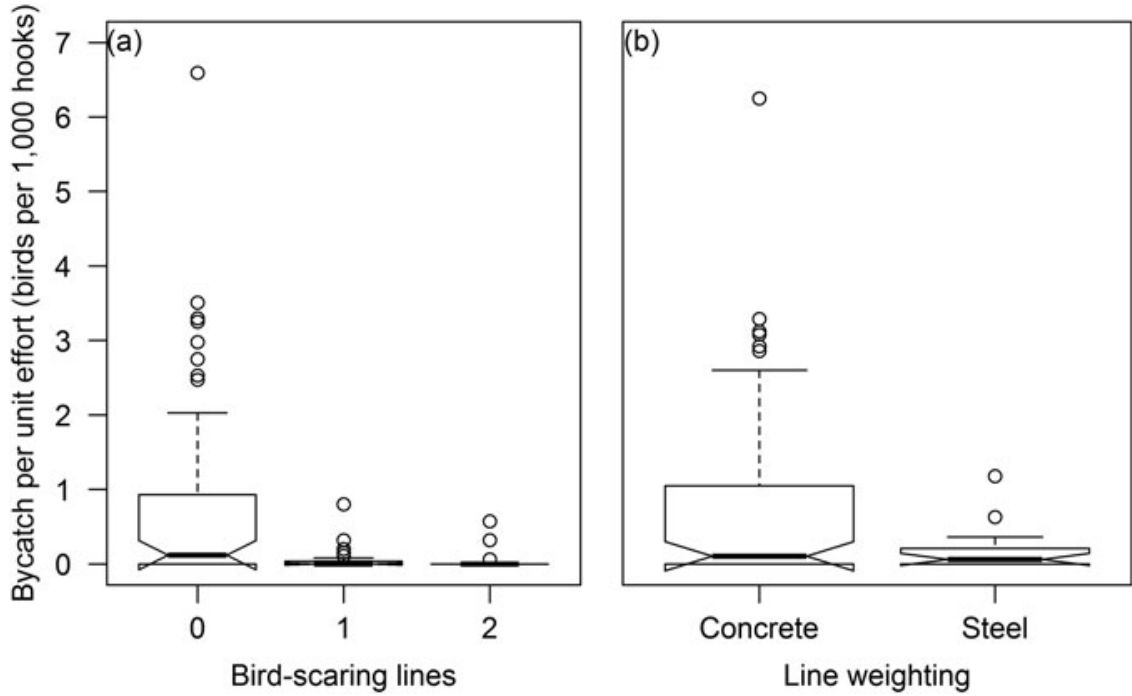

FIG. 2 Box plots (median; 25th-75th percentiles) of seabird bycatch rate (birds per 1,0oo hooks) in the Namibian demersal longline fishery (Fig. 1) for (a) zero (control), one and two bird-scaring lines, and (b) concrete weights (control) and $5 \mathrm{~kg}$ steel weights. Whiskers represent $1.5 \times$ the interquartile range, and dots represent outliers.

TABLE 4 Mean \pm SD time to depth and sink rate $\left(\mathrm{ms}^{-1}\right)$ for hooks set at the mid-point between weights on lines deployed using steel and concrete weights in the Namibian demersal longline fishery.

\begin{tabular}{llllllll}
\hline & \multicolumn{2}{l}{ Steel weights $(\mathrm{n}=24)$} & & & \multicolumn{3}{l}{ Concrete weights $(\mathrm{n}=24)$} \\
\cline { 2 - 3 } & $2 \mathrm{~m}$ & $4 \mathrm{~m}$ & $6 \mathrm{~m}$ & & $2 \mathrm{~m}$ & $4 \mathrm{~m}$ & $6 \mathrm{~m}$ \\
\hline Time to depth $(\mathrm{s})$ & $16 \pm 0.6$ & $24 \pm 0.9$ & $32 \pm 1.25$ & & $22 \pm 0.6$ & $34 \pm 1.1$ & $46 \pm 1.4$ \\
Sink rate $\left(\mathrm{ms}^{-1}\right)$ & 0.13 & 0.17 & 0.19 & & 0.09 & 0.12 & 0.13 \\
Distance astern $(\mathrm{m}) *$ & 65.8 & 98.7 & 131.6 & 90.5 & 139.9 & 189.3 \\
\hline
\end{tabular}

${ }^{*}$ Assumes a setting speed of 8 knots

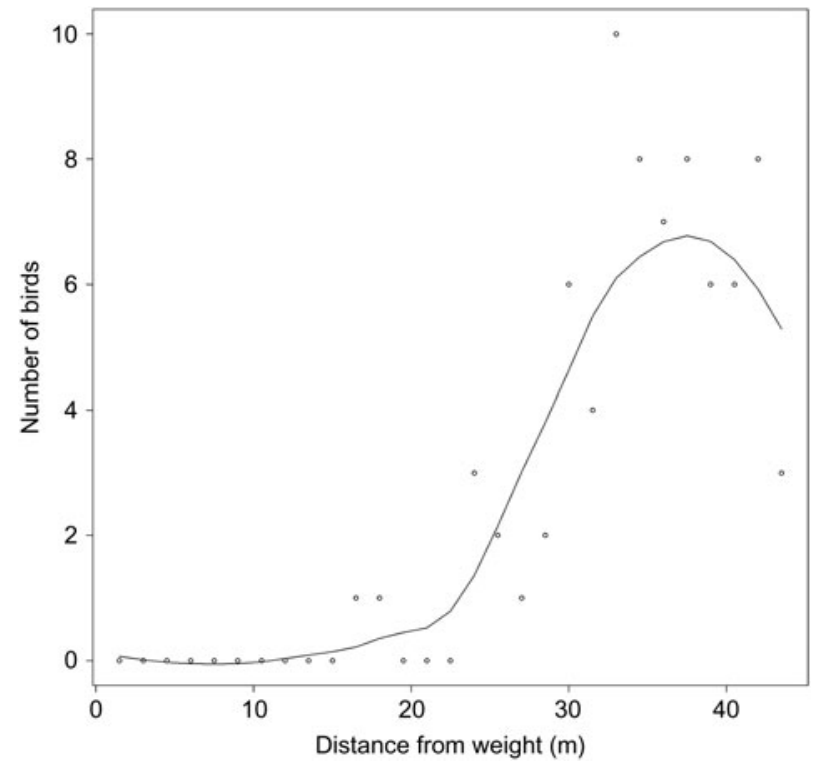

FIG. 3 Position of seabirds recovered on hook lines in relation to concrete line weighting in the Namibian demersal longline fishery (Fig. 1). Data collected from a single trip in 2012.

improving the level of observer coverage substantially and including official fisheries data in our estimate, the new estimate of $20,567(6,328-37,935)$ birds per year is similar to the original, and confirms that this fishery has one of the highest known levels of seabird bycatch in global longline fisheries (Anderson et al., 2011). The development of this new seabird bycatch estimate is important as the larger sample size provides further credibility to the scale of bycatch in the fishery, and thus facilitates decision making within fishery management stakeholder groups. However, this estimate would be improved by an increased level of seabird bycatch monitoring in the fishery.

We also present the first experimental trials of mitigation measures for this fishery. The three mitigation measures tested (paired bird-scaring lines, single bird-scaring lines and $5 \mathrm{~kg}$ steel line weights) all resulted in significant reductions in the rate of seabird bycatch, providing new evidence that the use of bird-scaring lines and improved line weighting are effective mitigation measures for seabird bycatch in demersal longline fisheries (Ashford et al., 1995; Agnew et al., 2000; Bull, 2007; Robertson et al., 2008).

Bird-scaring lines have been found to be effective in reducing seabird bycatch in other demersal longline fisheries. A single line reduced bycatch of northern fulmars Fulmarus glacialis by $98 \%$ in the North Atlantic (Løkkeborg, 2003), and paired bird-scaring lines reduced bycatch of surfaceforaging seabirds by $88-100 \%$ in the Alaskan sablefish and cod fishery (Melvin et al., 2001). A subsequent review of the 
effectiveness of bird-scaring lines by Melvin et al. (2004) recommended paired bird-scaring lines be used in all demersal fisheries, particularly to avoid the reduction in mitigation effectiveness caused by crosswinds or low wind conditions. However, we found that both single and paired bird-scaring lines were effective in reducing seabird bycatch for the fishing gear configuration and the seabird assemblage reported here. Moreover, no albatrosses were caught when birdscaring lines were deployed. We note that the predominant wind direction in the fishery is southerly and vessels tend to set and retrieve gear in a north-south or south-north direction, which may limit the negative effects of crosswinds on bird-scaring lines.

Bird-scaring lines work by protecting the area at the sea surface where baited hooks are sinking. Therefore, achieving a sink rate that removes baited hooks from the reach of foraging seabirds within the aerial extent of a bird-scaring line is necessary to maximize the benefit from this mitigation measure. We found the sink rate of standard fishing gear in the Namibian fishery to be extremely slow. The mean mass of the concrete weights currently used in this fishery is $3.69 \mathrm{~kg}$, with weights deployed at intervals of $96 \mathrm{~m}$. According to our time-depth recorder analysis the associated sink rate is $0.12 \mathrm{~ms}^{-1}$ to a depth of $4 \mathrm{~m}$ and $0.15 \mathrm{~ms}^{-1}$ to $10 \mathrm{~m}$, which is c. $50 \%$ of that of the optimum line weighting configurations achieved by Robertson et al. (2008). By using $5 \mathrm{~kg}$ steel weights it was possible to increase the sink rate of baited hooks to $0.17 \mathrm{~ms}^{-1}$ to a depth of $4 \mathrm{~m}$ and 0.22 $\mathrm{ms}^{-1}$ to $10 \mathrm{~m}$. The use of steel instead of concrete is an improvement, as concrete has the propensity to break down at sea, resulting in significant variation in the mass of weights and the need for frequent replacements. Although the steel weights give an improved sink rate, they compare poorly with the $8.5 \mathrm{~kg}$ every $40 \mathrm{~m}$ or $6 \mathrm{~kg}$ every $20 \mathrm{~m}$ that is recommended by the Commission on the Conservation of Antarctic Marine Living Resources, following Agnew et al. (2000). As the white-chinned petrel, the main species caught in the Namibian fishery, is able to forage down to a maximum depth of $16 \mathrm{~m}$ (Rollinson et al., 2014), the sink rate in this fishery would benefit from further improvements.

According to best practice criteria for seabird bycatch mitigation outlined in the Agreement on the Conservation of Albatross and Petrels, 'Fishing technologies and techniques should, to the extent practicable, maintain catch rates of target species. This approach should increase the likelihood of acceptance and compliance by fishers.' (ACAP, 2014, p. 4). The reason for the longer distance between line weights in the Namibian fishery compared to that recommended by the Commission on the Conservation of Antarctic Marine Living Resources is that both target species feed above the sea-floor at night (Gordoa \& Macpherson, 1991), migrating vertically in the water column, and fishing captains therefore prefer to have sections of line that loft above the sea-floor, which requires greater spacing between weights. This greater distance between weights creates lofting of the hook line during setting, which we have shown is reflected in birds being caught at the slowest sinking point of the line in close proximity to the unweighted dropper lines, similar to results found in Argentina (Seco Pon et al., 2007). To achieve an acceptable sink rate without jeopardizing the fish catch rate, the fishing gear could potentially be modified to an alternative configuration, as described in Moreno et al. (2006).

However, according to our results the use of one or two bird-scaring lines is effective at reducing seabird bycatch in this fishery, particularly in relation to albatrosses, and improved line weighting also reduces total seabird bycatch. Moreover, our initial results indicate that steel weights have no effect on target species catch rates. Anecdotally, the fishing master of the vessel used for experimental trials suggested that the heavier steel weights helped prevent the gear from drifting across the seabed, and therefore were beneficial in avoiding gear loss and entanglements. This could serve as an additional conservation benefit in terms of reducing plastic waste and ghost fishing but more work is needed to confirm this effect.

Although we found that both bird-scaring lines and improved line weighting reduced the bycatch rate, we found no difference in overall seabird bycatch during daylight and nocturnal sets. We believe this is because the seabird bycatch was dominated by white-chinned petrels, which are proficient nocturnal foragers and are therefore one of the species most vulnerable to fishery interactions (Mackley et al., 2011). By contrast, albatross bycatch was up to an order of magnitude higher during the day in winter. We therefore support the best practice advice of the Agreement on the Conservation of Albatross and Petrels for demersal longline fisheries; i.e. the use of a combination of all three measures in the Namibian longline fishery.

\section{Policy implications}

This study was conducted following the advice set out in the FAO Best Practice Technical Guidelines (FAO, 2008). The initiative was driven by local and international NGOs, but government and industry participation were critical aspects of the process from the outset. Once the results from at-sea monitoring were concluded, a series of stakeholder consultation workshops were conducted to ensure a strong education and outreach campaign. This was accompanied by parallel discussions with the Ministry of Fisheries and Marine Resources to advocate the introduction of new regulations that would make the use of seabird bycatch mitigation measures obligatory for the hake fishery.

Namibia formulated its National Plan of ActionSeabirds in 2012 and a Hake Management Plan was formally 
adopted in October 2014. Both plans recommend the adoption of bird-scaring lines as mitigation measures, and the National Plan of Action-Seabirds calls for an $80 \%$ reduction of seabird bycatch in this fishery. The draft regulations for the National Plan of Action-Seabirds was sent for legal review in November 2014 and in November 2015 these regulations were gazetted, making the use of a combination of bird-scaring lines, line weighting and night setting mandatory for the hake fishery. The collaboration between industry and government was important to achieve a wide understanding and acceptance of the proposed mitigation measures in the lead up to the introduction of fishery regulations. We recommend that similar projects in future should refer to the FAO Best Practice Technical Guidelines at the earliest stage possible. As this study represents a relatively small subsample of the fishing fleet effort, and mitigation measures were used during a limited number of experimental tests, we also recommend further monitoring and a subsequent review of the Namibian demersal longline fishery, to evaluate fully the adequacy and efficacy of the proposed measures.

\section{Acknowledgements}

We thank the Ministry for Fisheries and Marine Resources, particularly Paulus Kainge for collaboration throughout the project and provision of fleet data. We thank the Fisheries Observer Agency for granting access to vessels, and in particular the owner and master of the MFV Joa N. Castro for allowing us to conduct line weighting comparisons. This work was performed as part of the Albatross Task Force in Namibia, hosted by the Namibian Nature Foundation. The project is supported by the Royal Society for the Protection of Birds (the BirdLife International partner in the UK) and was funded by a grant from the Adessium Foundation through Vogelbescherming, BirdLife Nederland. The article was improved thanks to comments from two anonymous reviewers.

\section{Author contributions}

JP and OY led on project design and data collection protocols, project management and preparation of the manuscript. HH provided project support and guidance throughout and contributed to manuscript preparation. TR conducted all data analysis and manuscript edits. KS and JP conducted all at-sea data collection. SY had a crucial role in stakeholder consultations and advocating the introduction of regulations. BS and RW provided guidance and oversight on all aspects of project management and manuscript preparation.

\section{References}

ACAP (2014) Report of the Sixth Meeting of the Seabird Bycatch Working Group. Unpublished report. ACAP, Punta del Este, Uruguay.

ACAP (2017) Agreement on the Conservation of Albatrosses and Petrels. Http://acap.aq/ [accessed 23 February 2017].

Agnew, D.J., Black, A.D., Croxall, J.P. \& Parkes, G.B. (2000) Experimental evaluation of the effectiveness of weighting regimes in reducing seabird by-catch in the longline toothfish fishery around South Georgia. CCAMLR Science, 7, 119-131.

Anderson, O.R., Small, C.J., Croxall, J.P., Dunn, E.K., Sullivan, B.J., YAtes, O. \& Black, A. (2011) Global seabird bycatch in longline fisheries. Endangered Species Research, 14, 91-106.

Ashford, J.R., Croxall, J.P., Rubilar, P.S. \& Moreno, C.A. (1995) Seabird interactions with longlining operations for Dissostichus eleginoides around South Georgia, April to May 1994. CCAMLR Science, 2, 111-122.

Bates, D., Maechler, M., Bolker, B. \& Walker, S. (2015) Fitting linear mixed-effects models using lme4. Journal of Statistical Software, 67, 1-48.

Birdife International (2016a) Procellaria aequinoctialis. In The IUCN Red List of Threatened Species 2016: e.T22698140A104916768. Http://dx.doi.org/10.2305/IUCN.UK.2016-3.RLTS.T22698140 A104916768.en [accessed 23 February 2017].

Birdife International (2016b) Species factsheet: White-chinned petrel Procellaria aequinoctialis. Http://www.birdlife.org [accessed 24 November 2016].

Brothers, N. (1991) Albatross mortality and associated bait loss in the Japanese longline fishery in the Southern Ocean. Biological Conservation, 55, 255-268.

Brothers, N., Cooper, J.P. \& Løkkeborg, S. (1999) The Incidental Catch of Seabirds by Longline Fisheries: Worldwide Review and Technical Guidelines for Mitigation. FAO Fisheries Circular No. 937. FAO, Rome, Italy.

BuLL, L.S. (2007) Reducing seabird bycatch in longline, trawl and gillnet fisheries. Fish and Fisheries, 8, 31-56.

Cherel, Y., Weimerskirch, H. \& Duhamel, G. (1996) Interactions between longline vessels and seabirds in Kerguelen waters and a method to reduce seabird mortality. Biological Conservation, 75, 63-70.

Croxall, J.P., Butchart, S.H.M., Lascelles, B., Stattersfield, A. J., Sullivan, B., Symes, A. \& Taylor, P. (2012) Seabird conservation status, threats and priority actions: a global assessment. Bird Conservation International, 22, 1-34.

Croxall, J.P., Rothery, P., Pickering, S.P.C. \& Prince, P.A. (1990) Reproductive performance, recruitment and survival of wandering albatrosses Diomedea exulans at Bird Island, South Georgia. Journal of Animal Ecology, 59, 775-796.

FAO (1999) International Plan of Action for Reducing Incidental Catch of Seabirds in Longline Fisheries. Http://www.fao.org/fishery/ ipoa-seabirds/en [accessed 9 October 2015].

FAO (2008) Report of the Expert Consultation on Best Practice Technical Guidelines for IPOA/NPOA-Seabirds. FAO Fisheries and Aquaculture Report. No. 880. FAO, Bergen Norway.

Furness, R.W. (2003) Impacts of fisheries on seabird communities. Scientia Marina, 67, 33-45.

Gelman, A., Carlin, J.B., Stern, H.S., Dunson, D.B., Vehtari, A. \& Rubin, D.B. (2014) Bayesian Data Analysis. 3rd edition. CRC Press, New York, USA.

GordoA, A. \& Macpherson, E. (1991) Diurnal variation in the feeding activity and catch rate of cape hake (Merluccius capensis and M. paradoxus) off Namibia. Fisheries Research, 12, 299-305. 
Jiménez, S., Domingo, A., Abreu, M. \& Brazeiro, A. (2012) Bycatch susceptibility in pelagic longline fisheries: are albatrosses affected by the diving behaviour of medium-sized petrels? Aquatic Conservation: Marine and Freshwater Ecosystems, 22, 436-445.

Jiménez, S., Domingo, A. \& Brazeiro, A. (2009) Seabird bycatch in the Southwest Atlantic: interaction with the Uruguayan pelagic longline fishery. Polar Biology, 32, 187-196.

LøKKEBORG, S. (2003) Review and evaluation of three mitigation measures-bird-scaring line, underwater setting and line shooterto reduce seabird bycatch in the north Atlantic longline fishery. Fisheries Research, 6o, 11-16.

LøккевоRG, S. (2011) Best practices to mitigate seabird bycatch in longline, trawl and gillnet fisheries-efficiency and practical applicability. Marine Ecology Progress Series, 435, 285-303.

Mackley, E.K., Phillips, R.A., Silk, J.R.D., Wakefield, E.D., Afanasyev, V. \& Furness, R.W. (2011) At-sea activity patterns of breeding and nonbreeding white-chinned petrels Procellaria aequinoctialis from South Georgia. Marine Biology, 158, 429-438.

Maree, B.A., Wanless, R.M., Fairweather, T.P., Sullivan, B.J. \& YAtEs, O. (2014) Significant reductions in mortality of threatened seabirds in a South African trawl fishery. Animal Conservation, 17, 520-529.

Melvin, E.F., Parrish, J.K., Dietrich, K.S. \& Hamel, O.S. (2001) Solutions to Seabird Bycatch in Alaska's Demersal Longline Fisheries. Unpublished report. Washington Sea Grant Program, Seattle, USA.

Melvin, E.F., Sullivan, B., Robertson, G. \& Wienecke, B. (2004) A review of the effectiveness of streamer lines as a seabird by-catch mitigation technique in longline fisheries and CCAMLR streamer line requirements. CCAMLR Science, 11, 189-201.

Ministry of Fisheries and Marine Resources (2013) Annual Report 2012-2013. Ministry of Fisheries and Marine Resources, Walvis Bay, Namibia.

Moreno, C.A., Arata, J.A., Rubilar, P., Hucke-Gaete, R. \& Robertson, G. (2006) Artisanal longline fisheries in Southern Chile: lessons to be learned to avoid incidental seabird mortality. Biological Conservation, 127, 27-36.

Petersen, S.L., Honig, M.B., Ryan, P.G., Underhill, L.G. \& Goren, M. (2009) Seabird bycatch in the demersal longline fishery off southern Africa. African Journal of Marine Science, 31, 205-214.

Plummer, M. (2015) JAGS Version 4.o.o User Manual. Http://www. uvm.edu/ bbeckage/Teaching/DataAnalysis/Manuals/manual.jags. pdf [accessed 23 November 2016].

R Development Core Team (2013) R: A Language and Environment for Statistical Computing. R Foundation for Statistical Computing, Vienna, Austria.

Reid, T.A. \& Sullivan, B.J. (2004) Longliners, black-browed albatross mortality and bait scavenging in Falkland Island waters: what is the relationship? Polar Biology, 27, 131-139.

Reid, T.A., Sullivan, B.J., Pompert, J., Enticott, J.W. \& Black, A. D. (2004) Seabird mortality associated with Patagonian toothfish
(Dissostichus eleginoides) longliners in Falkland Islands waters. Emu, 104, 317-325.

Robertson, G., Moreno, C.A., Gutiérrez, E., Candy, S.G., Melvin, E.F. \& SeCo Pon, J.P. (2008) Line weights of constant mass (and sink rates) for Spanish-system Patagonian toothfish longline vessels. CCAMLR Science, 15, 93-106.

Rollinson, D.P., Dilley, B.J. \& Ryan, P.G. (2014) Diving behaviour of white-chinned petrels and its relevance for mitigating longline bycatch. Polar Biology, 37, 1301-1308.

Seco Pon, J.P., Gandini, P.A. \& Favero, M. (2007) Effect of longline configuration on seabird mortality in the Argentine semi-pelagic Kingclip Genypterus blacodes fishery. Fisheries Research, 85, 101-105.

Shotwell, M. (2013) Applied nonparametric bootstrap with hierarchical and correlated data. Http://biostat.mc.vanderbilt.edu/ wiki/Main/HowToBootstrapCorrelatedData [accessed 26 October 2013].

Venables, W.N. \& Ripley, B.D. (2002) Modern Applied Statistics with S. 4 th edition. Springer, New York, USA.

Weimerskirch, H., Brothers, N. \& Jouventin, P. (1997) Population dynamics of wandering albatross Diomedea exulans and Amsterdam albatross D. amsterdamensis in the Indian Ocean and their relationships with longline fisheries: conservation implications. Biological Conservation, 79, 257-270.

Weimerskirch, H., Catard, A., Prince, P.A., Cherel, Y. \& Croxall, J.P. (1999) Foraging white-chinned petrels Procellaria aequinoctialis at risk: from the tropics to Antarctica. Biological Conservation, 87, 273-275.

\section{Biographical sketches}

John Paterson managed the Albatross Task Force in Namibia during 2009-2013, concentrating on demersal longline fisheries. OLIVER YAtes manages BirdLife International's Albatross Task Force. Previously he worked at sea as an observer in the Falkland Islands and coordinated the Albatross and Petrel Programme for Falklands Conservation. Hannes Holtzhausen is a fisheries biologist and an initiator of the Namibian Plan of Action for the Conservation and Management of Sharks and the National Plan of ActionSeabirds. TIM REID is a biologist and statistician specialized in seabird ecology and seabird interactions with fisheries. KASPAR SHIM OOSHILI worked as an Albatross Task Force instructor in Namibia during 20082011. Sarah Yates was the Albatross Task Force Manager during 2013-2014. BEN SULLIVAN's early work on seabird bycatch and development of mitigation measures led to the launch of the Albatross Task Force, and he has driven the development of innovative technology to encapsulate baited hooks and line weighting technology for pelagic longline fisheries. Ross WANLESS is the Africa Coordinator for the BirdLife International Marine Programme and the Seabird Conservation Programme manager for BirdLife South Africa. 